\title{
Запалване на ендотрахеална трьба по време на лазерна микроларингохирургия - клиничен случай и анализ
}

\author{
И. Чальков ${ }^{1}$, Н. Сапунджиев², И. Ценев ${ }^{1}$, \\ Т. Ковачев ${ }^{3}$, М. Мирчева ${ }^{3}$ \\ ${ }^{1}$ Клиника по УНГ-болести, УМБАЛ "Царица Йоанна" - София \\ ${ }^{2}$ Клиника по УНГ-болести, УМБАЛ "Св. Марина" - Варна \\ ${ }^{3}$ Клиника по анестезиология УМБАЛ "Царица Йоанна" - София
}

Abstract

Background: Endotracheal tubus (ETT) fire during endoscopic laser surgery is a rare but disastrous complication with high mortality. The standard emergency guidelines to such event include extubate, eliminate, extinguish and evaluate (,the four Es“ rule). Case: A 52-year-old man with severe respiratory compromise due to bilateral vocal fold paralysis was subjected to routine endoscopic laser posterior partial chordectomy. Ventilation was maintained through a polyvinylchloride ETT covered with metal foil. The cuff was inflated with air and protected in the routine manner with a wet gauze. Anestesia was maintained with $\mathrm{N}_{2} \mathrm{O} / \mathrm{O}_{2}(50 / 50 \%)$. The larynx was exposed through Kleinsasser's $\mathrm{C}$ laryngoscope. The $\mathrm{CO}_{2}$ laser was operated with the micromanipulator under operating microscope in continuous mode with power settings $15 \mathrm{~W}$. Fourteen minutes after the start of the operation ETT fire occurred. In 2 seconds $50 \mathrm{ml}$ saline were jet poured through the laryngoscope with a syringe and the fire extinguished. The patient was extubated and then reintubated and slowly woken. High dose cortisone was administered. The respiration was good and did not require tracheotomy. Postoperative laryngoscopy revealed minor burn signs - edema and redness.

Conclusion: In the presented case the ,extinguish first“ strategy allowed for immediate stop of the fire. Further advantages of this approach include: immediate temperature sunk at the place of fire, cut off of gas propagation, keeping the ETT at place in the first moment and lavage of depositions of ash.

\section{Резюме}

Въведение: Запалването на ендотрахеалната тръба (ЕTT) по време на ендоскопска лазерна микрохирургия на ларинкса е рядко, но много тежко усложнение, характеризиращо се с висока смъртност. Стандартният „АБВ“ алгоритъм на поведение при такъв случай включва екстубиране, прекъсване на газовете, гасене на остатьчен пламък и преценка на пораженията.

Клиничен случай: При 52-годишен пациент бе предприета стандартна ендоскопска лазерна частична задна хордектомия по повод двустранна парализа на гласните връзки с диспнея. Вентилацията се осъществяваше с PVC ETT, протектирана с

\section{Въведение}

Общиятпринципналазера (LASER-LightAmplification by Stimulated Emission of Radiation) е открит през 1960 г. от Maiman. Много скоро след това започват активни експерименти в най-различни области за проучване евентуални приложения на този физически феномен в практиката. Още в този ранен етап медицината е едно от водещите експериментални направления. Първите използвани лазери са рубинов и Nd-in-glass. Правени са опити за приложение в сферата на онкологията, но резултатите били разочароващи. Апарати, емитиращи фокусиран лазерен лъч от $\mathrm{CO}_{2}$, са конструирани през 1965 г. Бързо са установени някои предимства на този тип лазерно лъчение - позволява не само изпаряване на тъканите, но и прецизно рязане, има хемостатичен ефект върху малките съдове в оперативната рана [16]. Strong и Jako първи въвеждат $\mathrm{CO}_{2}$-лазера за микрохирургия на ларинкса в началото на седемдесетте години на $\mathrm{XX}$ в. В днешно време $\mathrm{CO}_{2}$-лазерьт се приема като рутинен инструмент в оториноларингологията.

Запалването на ендотрахеалната тръба по време на ендоскопска лазерна микрохирургия на ларинкса е рядко, но много тежко усложнение. Първият подобен случай е описан през 1979 г. [2]. Средно при 1 на 1300 ендоскопски лазерни интевенции в ларинкса има вероятност да възникне запалване на ендотрахеалния тубус. По различни данни смътността варира от $10 \%$ до 50\% [15]. Стандартният „АБВ“ алгоритъм на поведение при подобни случаи включва екстубиране, прекъсване на газовете, гасене на остатъчен пламък и преценка на пораженията. 
метално фолио. Допълнително балонът на ЕТT бе протектиран с компрес, напоен с вода. Поддържането на анестезията бе чрез газова смес $\mathrm{N}_{2} \mathrm{O} / \mathrm{O}_{2}(50 / 50 \%)$. $\mathrm{CO}_{2}$-лазерният лъч (continuous mode, $15 \mathrm{~W}$ ) бе управляван под микроскопски контрол с помощта на микроманипулатора през ларингоскоп тип Kleinsasser C. Четиринадесет минути след началото на интервенцията ЕТТ се запали с пламък. Последният бе потушен в рамките на 3 сек. чрез вливане под налягане на 50 мл физиологичен серум. Пациентът бе екстубиран, поставен бе нов здрав ЕТТ и постепенно изведен от анестезията. Приложен бе кортикостероид венозно. Болният възстанови добро дишане, без да се налага извършването на трахеотомия. Контролната ларингоскопия установи единствено хиперемия и лек оток, без други сериозни поражения

Заключение: В представения случай подходът за незабавно инстилиране на серум позволи пълно гасене на пламналата ETT. По този начин се постигна и максимално бързо понижаване на температурата в областта на запалването, блокиране проникването на горещи газове, запазване на първо време на ЕTT в дихателния път и лаваж на частиците от горенето.

\section{Клиничен случай}

При 52-годишен пациент бе предприета стандартна ендоскопска лазерна частична задна хордектомия (ляво) по повод двустранна парализа на гласните връзки с диспнея. Въвеждането в анестезия се извърши по стандартна схема с барбитурат и релаксант. Вентилацията се осъществяваше с PVC ендотрахеална тръба (RUSCH, O.D. 8.7, I.D. 7.0), протектирана с метално фолио (Фиг. 1). Поддържането на анестезията бе чрез газова смес $\mathrm{N}_{2} \mathrm{O} / \mathrm{O}_{2}(50 / 50 \%)$. Допълнително балонът на тубуса бе покрит с марлен компрес, напоен с вода. $\mathrm{CO}_{2}$-лазерният лъч (Sharplan 1040) бе в continuous mode с мощност $15 \mathrm{~W}$ и бе управляван под микроскопски контрол (Zeiss OpMi 6) с помощта на микроманипулатора през директен ларингоскоп тип Kleinsasser C. Четиринадесет минути след началото на интервенцията възникна запалване на ендотрахеалната тръба с ярък пламък. Последният бе потушен в рамките на няколко секунди чрез вливане под налягане на физиологичен серум с 50-кубикова спринцовка. Пациентът бе екстубиран, горните дихателни пътища бяха аспирирани и бе поставна нова здрава ендотрахеална тръба. Започна се извеждане от анестезията. Приложен бе кортикостероид венозно. Болният възстанови добро дишане, без да се налага извършването на трахеотомия. При контролната ларингоскопия на следващия ден бяха установени хиперемия и лек оток, без други сериозни поражения. Следоперативният период премина спокойно под антибиотична защита и при прилагане на системен кортикостероид. Шест седмици след изписването пациентьт се яви отново на контролен преглед. Ларингоскопската находка показа рестеноза на ларинкса с образуване на цикатрикс (адвентициална гласна връзка) в областта на хордектомията вляво.

\section{Обсъждане}

При лазерната резекция на тъкани в областта на горните аеро-дигестивни пътища в непосредствена близост са два рискови фактора за запалване - кислород и източник на запалителна енергия - лазерът [6]. Разделени са само от стената на интубационната тръба. Срещането им резултира с много голяма вероятност в избухване на открит огън със засягане материала на тубуса и с газов факел. Оказва се, че подобни инциденти не са чак толкова голяма рядкост в лазерната хирургия. Според различни публикации от въвеждането на $\mathrm{CO}_{2}$-лазера в оториноларингологичната хирургична практика през седемдесетте до 1985 г. честотата на подобни ициденти е около 0.4-1.5\%. Предполага се обаче, че реално броят на подобни инциденти и респективно честотата им е доста по-висока [6]. 
Хипотезират се няколко механизма на самото запалване на ендотрахеалния тубус под въздействие на лазерен лъч - директно попадане на льча върху тубуса [4], прескачане на огъня от горящи тъкани в областта на върха на тубуса [8] или когато запалими анестетични газове влязат в контакт с ,нагорещения“ от лазера дихателен път [14]. Времето, през което тези фактори си взаимодействат до възникване на запалване, може да варира значително - от десетки секунди [13] до по-малко от секунда - определящи са матеральт, от който е направен тубусът, концентрацията на кислорода и режимът на работа на лазера.

Според някои публикации рискът за възникване на запалване на тубуса по време на ендоскопска лазерна хирургия е обратно пропорционален на опита на хирургичния екип - наблюдава се така наречената крива на обучение (learning curve). При начинаещи рискът от подобен инцидент е повисок - 1/250 [2], 4/700 [17] до 2/3000 [14]. Един наскоро публикуван метаанализ обаче подсказва, че макар и безспорно от огромно значение, опитът на хирурга не е гаранция за избягване на подобни инциденти. Дори хирурзи с дългогодишен опит в микроскопската лазерна хирургия не са застраховани от подобни усложнения [15]. Това се обяснява и с по-сложния характер на провежданите от тях оперативни интервенции.

Топлинното увреждане на долните дихателни пътища е изключително опасно състояние, което може бързо да доведе до обструкция и екзитус. Три са патофизиологичните механизми: 1) директен топлинен ефект (самото изгаряне); 2) токсично действие на продуктите на горенето; 3) продължителната интубация [3].

От въвеждането на ендоскопската $\mathrm{CO}_{2}$-лазерна хирургия в клиниката по оториноларингология на МБАЛ „Царица Йоанна“ са проведени около 3200 подобни интервенции. Това е първият случай на запалвне на тубуса въпреки взетите стандартни предпазни мерки. В многогодишната ни практика обаче сме се сблъсквали и с други, не толкова драматични усложнения, най-честото от които - спукване на въздушния балон на тубуса от лазерния лъч без възникване на запалване (8 случая).

В клиничната практика са били тествани редица технически приспособления, имащи за цел предпазване на тубуса от въздействие на лазерния лъч/запалване:

\section{1. Анестезиологични похвати}

1.1. Използване на незапалими анестетични газове

1.1.1. Смес кислород с Isoflurane [17]

\subsection{2. Смес азотен окис:кислород $(60 \%: 40 \%)[2,5]$}

1.2. Обдишване през трахеостома [17]

1.3. Обдишване през трахеален катетьр [11]

1.4. Опериране в интермитираща апнея [7, 9]

1.5. Јet-вентилация [5,9]

1.6. Намаляване на кислородната концентрация в момента на прилагане на лазера [2, 7]

1.7. Използване на назофарингеален катетьр

1.8. Изпълване балона на тубуса с физиологичен серум [9, 10]

\section{2. Хирургични похвати}

2.1. Протектиране на тубуса/балона с мокри компреси [4]

2.2. Инструменти с матови, нерефлектиращи повърхности

2.3. Постоянна аспирация на дима за подобряване на визуализацията [5]

\section{3. Технически приспособления}

3.1. Трахеален тубус, обвит с алуминиево фолио [2, 17]

3.2. Специални тубуси с повишена устойчивост на лазерно лъчение

3.3. Флексибилни, изцяло метални ендотрахеални тубуси $[7,12]$

Дискусиите за резистентността на различните видове материали, използвани за производство на ендотрахеални тубуси (червена гума, PVC, силикон, тефлон) срещу запалване, не са довели до консенсус - няма достоверни данни за значително преимущество на един от материалите в сравнение с останалите [1]. С най-висок риск за възпламеняване при контакт с лазер са PVCтубусите [4]. Експериментите, в които е тесувана запалимостта и безопасността на различните тубуси, имат доста различни опитни постановки и са използвани различни концентрации на кислорода. Минимални изтичания на кислород от системата при недобро уплътняване компрометират силно безопасността $[1,4]$. Прилагането на метализирано фолио за обвиване на тубуса е много добра защита за покритите части, но оставя открити най-слабите им места - балона и върха [1].

Анализ на 15 случая на запалване на тубус показва, че при 6 от тях са били взети една или няколко от описаните предпазни мерки, но въпреки това е настьпило запалване. За момента няма общоприета единна стандартна предпазна процедура, понеже поотделно или в комбинация всяко от тези технически приспособления също не гарантира пълна сигурност [15].

Подходът за излизане от подобно положение е стандартен. В англоезичната литература общопри- 
ето е правилото на четирите „Е“. Extract (изваждане на тубуса), Eliminate (елиминиране достъпа на кислород), Extinguish (загасяне на остатъчни горящи парчета пластмаса в дихателните пътища, Evaluate (оглед на настьпилите поражение с ендоскопска техника) [18]. В представения от нас случай наличието на готова 50-милилитрова спринцовка с физиологичен серум позволи в рамките на няколко секунди пламъкът да бъде напълно потушен при оставане на тубуса в трахеята и запазване положението на директния ларингоскоп. Този подход показа следните предимства: бързо елиминиране на пламъка; буфериране на температурата с хладна топлоемка течност и по този начин предпазване на тъканите от продължаващо топлинно въздействие; запазване на първо време на дихателна тръба (макар и увредена) в трахеята; лаваж на карбонизирани частици; не се налага изтегляне на горящ тубус през по-горните нива.

\section{Заключение}

Запалването на трахеалния тубус по време на ендоскопска $\mathrm{CO}_{2}$-лазерна хирургия на ларинкса/ хипофаринкса е реална опасност, която въпреки редкостта си не трябва да се подценява. Трябва да се има предвид, че подобни инциденти възникват независимо от взетите технически предпазни мерки, както при по-неопитни, така и при хирурзи с дългогодишен богат опит. В представения случай подходът за незабавно инстилиране на серум позволи пълно гасене на пламналата

\section{Библиография:}

1. Arnold J, Allphin A (1992) Effects of Extraluminal Oxygen on Carbon Dioxide Laser Ignition of Endotracheal Tubes. Arch Otolaryngol Head Neck Surg 118: 722-724.

2. Burgess G, LeJeune FJ (1979) Endotrachel Tube Ignition During Laser Surgery of the Larynx. Arch Otolaryngol 105: 561-562.

3. Flexon P, Cheney M, Montgomery W, Turner P (1989) Management of Patients with Glottic and Subglottic Stenosis Resulting from Thermal Burns. Ann Otol Rhinol Laryngol 98:27-30.

4. Fontenot R, Bailey B, Stiernberg C, Jenicek J (1987) Endotracheal Tube Safety During Laser Surgery. Laryngoscope 97: 919-921.

5. Friedrich G, Mausser G, Nemeth E (2002) Entwicklung eines Jet-Tracheoskops. HNO 50: 719-726.

6. Gehring H (2002) Risiken des Sauerstoffs in der Laserchirurgie. Anaesthesiol Intensivmed Notfallmed Schmerzther 37: 29-57.

7. Hawkins D, Joseph M (1990) Avoiding a wrapped endotracheal tube in laser laryngeal surgery: Experiences with apneic anesthesia and metal laser-flex endotracheal tubes. Laryngoscope 100: 1283-1287.

8. Hirshmann C, Smith J (1980) Indirect Ignition of the Endotracheal Tube During Carbon Dioxide Laser Surgery. Arch Otolaryngol 106: 639-641.

9. Jeckström W, Wawerisk J, Werner J (1992) Narkosetechnik bei laserchiurgischen Eingrifen im Kehlkopfbereich. HNO 40:2 8-32.

10. LeJeune FJ, Guice C, LeTard F, Marice H (1982) Heat sink protection against lasering endotracheal cuffs. Ann Otol Rhinol Laryngol 91: 606-607. ендотрахеална тръба. Анализът на публикации по темата показва, че възможността за запалване на интратрахеалния тубус под въздействие на хирургичния $\mathrm{CO}_{2}$-лазер не трябва да се възприема като любопитна казуистика, а като реална потенциална опасност, произтичаща от естеството на хирургичното пространство и непосредствената близост на високоенергийното лазерно излъчване със запалими и поддържащи горенето материали и газове. В клинични центрове, където се прилага ендоскопска лазерна хирургия на горните аеродигестивни пътища, трябва да има разработени алгоритми и да се провежда обучение на персонала за действия в случай на възникване на интракавитарно запалване на анестезиологичния трахеален тубус.

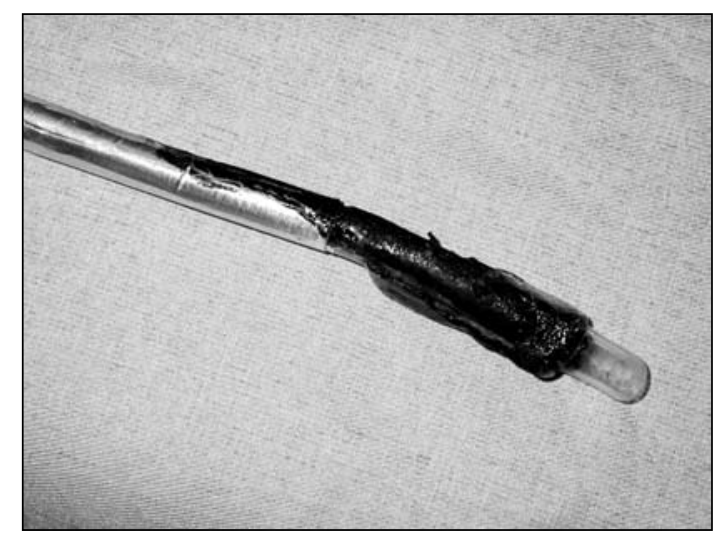

Фигура 1. Следи от запалването по тубуса. Огънят е възникнал в най-слабото място - балона. Метализираното фолио представлява много добра защита.

11. Monnier P, Ravussin P, Savary M, Freeman J (1988) Percutaneous transtracheal ventilation for laser endoscopic treatment of laryngeal and subglottic lesions. Clin Otolaryngol 13: 209-217.

12. Norton M, de Vos P (1978) New endotracheal tube for laser surgery of the larynx. Ann Otol Rhinol Laryngol 87: 554-557.

13. Ohashi N, Asai M, Ueda S, Imamura J, Watanabe Y, Mizukoshi K (1985) Hazard to Endotracheal Tubes by $\mathrm{CO}_{2}$ Laser Beam. Experimental report. ORL 47: 22-25.

14. Romanet P, Morizot B (1993) Les accidentes et les incidents de l'utilisatoin du laser $\mathrm{CO}_{2}$ en ORL. In: Le Laser en ORL. (Freche, C., ed) Arnette, Paris, p 78-83

15. Sesterhenn A, Dunne A, Braulke D, Lipert B, Folz B, Werner J (2003) Value of Endotracheal Tube Safety in Laryngeal Laser Surgery. Lasers in Surgery and Medicine 32: 384-390.

16. Simpson GT, 2nd, Polanyi TG (1983) History of the carbon dioxide laser in otolaryngologic surgery. Otolaryngol Clin North Am 16: 739-52.

17. Snow J, Norton M, Saluja T, Estanislao A (1976) Fire Hazard During $\mathrm{CO}_{2}$ Laser Microsurgery on the Larynx and Trachea. Anesth Analg 55.

18. Werkhaven J (2004) Microlaryngoscopy-airway management with anaesthetic techniques for $\mathrm{CO}_{2}$ laser. Pediatric anesthesia 14: 90-94. 